\title{
KEUTAMAAN BELAJAR DAN MENGAJARKAN AL-QUR'AN: Metode Maudhu'i dalam Perspektif Hadis
}

\author{
Muzakkir \\ Fakultas Tarbiyah dan Keguruan UIN Alauddin Makassar \\ Kampus II: Jalan Sultan Alauddin Nomor 36 Samata-Gowa \\ Email: muzakkir.ftkuin@gmail.com
}

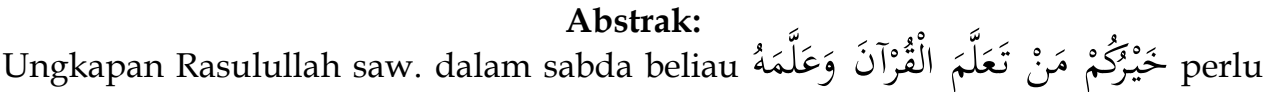
dikaji/diteliti kesahihannya agar dapat menimbulkan motiviasi yang tinggi bagi umat Islam untuk mengamalkannya. Berdasarkan hasil penelusuran sanad dan matan hadis melalui sumber yang banyak dan yang dijadikan fokus kajian adalah HR. Imam at-Turmudzy dapat disimpulkan bahwa hadis dimaksud adalah berkualitas sahih. Dengan demikian, al-Qur'an sebagai bacaan sempurna bagi umat Islam yang memiliki kaidah tertentu dalam membacanya, mulai dari penyebutan huruf-hurufnya, panjang pendeknya, tebal tipisnya serta ketentuan makharijul hurufnya perlu dipelajari dan diajarkan secara tekun dan sungguhsungguh. Belajar al-Qur'an mencakup upaya mempelajari cara membacanya, terjemah, dan memahami hukum-hukum, pelajaran-pelajaran, petunjuk-petunjuk yang terkandung di dalamnya. Begitu pula, mengajarkan al-Qur'an mencakup upaya menuntun dan membimbing orang dalam membaca, menerjemah dan memahamkan kandungan ayat-ayat al-Qur'an. Orang yang melakukannya secara ikhlas dan sungguh-sungguh akan mendapatkan keutamaan dari al-Qur'an berupa ketenangan, ketenteraman hati dan pikiran serta syafaat di akhirat kelak.
\end{abstract}

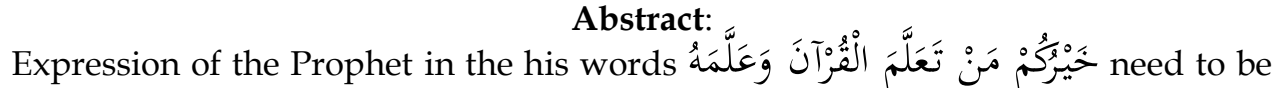
examined/investigated its validity in order to generate high motivation for Muslims to practice it. Based on the search results of sanad and Matan of the hadith through many sources and where the focus of the study were Jami at-Tirmidhi, it can be concluded that the quality of hadith was valid. Thus, the Qur'an as a perfect reading for Muslims who has certain rules in reading, from the mention of the letters, the short or the length, the thickness and the provisions of makharijul of letters need to be learned and taught diligently and earnestly. Learning alQur'an includes efforts to learn how to read them, to translate and to understand the laws, the lessons, the instructions contained therein. Likewise, teaching alQur'an includes efforts to lead and guide people to read, to translate and to understand the content of the verses of al-Qur'an. People who do it sincerely and earnestly will get the primacy of the al-Qur'an in the form of tranquility, peace of heart and mind as well as the intercession in the Hereafter.
\end{abstract}

Kata kunci:

Alquran, belajar, dan mengajarkannya

AL-QUR'AN yang secara harfiah berarti “bacaan sempurna” merupakan suatu nama pilihan Allah yang sungguh tepat, karena tiada suatu bacaan pun sejak manusia mengenal tulis baca lima ribu tahun yang lalu yang dapat menandingi Al-Qur'an alKarim, bacaan sempurna lagi mulia itu. ${ }^{1}$ 
Al-Qur'an adalah sebuah kitab suci yang sakral. Tidak ada satu kitab pun di dunia ini yang dihapal di luar kepala jutaan orang, selain al-Qur'an karena Allah telah menjadikannya mudah diingat dan dihapal. Sekalipun banyak orang yang menghapalnya tidak paham apa yang dibaca dan dihapalnya karena berbahasa Arab, namun mereka berlomba-lomba menghapalnya dengan maksud sebagai ibadah dan mendekatkan diri kepada Allah swt.

Allah swt. menurunkan al-Qur'an untuk menunjuki manusia ke tujuan yang paling utama dan jalan yang paling lurus. Firman Allah dalam Q.S. al-Isra (17): 9

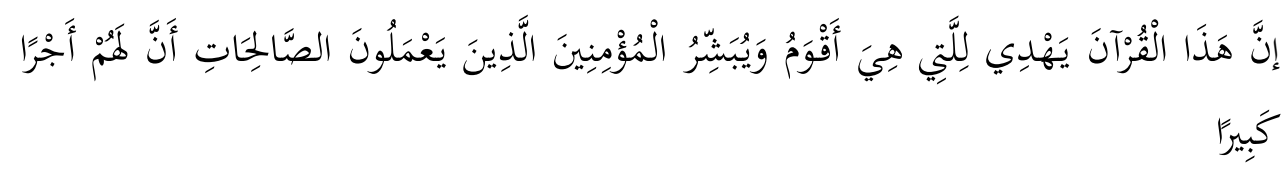

Sesungguhnya al-Qur'an ini memberikan petunjuk kepada (jalan) yang lebih lurus dan memberi khabar gembira kepada orang-orang Mu'min yang mengerjakan amal saleh bahwa bagi mereka ada pahala yang besar. ${ }^{2}$

Sumber ajaran Islam yang kedua setelah al-Qur'an adalah al-Hadis. Dalam ayatayat al-Qur'an dikatakan bahwa Nabi Muhammad saw. sebagai Nabi dan Rasul Allah mesti diikuti petunjuk-petunjuknya. Hal tersebut juga mengindikasikan bahwa hadishadis Nabi saw., di samping sumber ajaran agama Islam, juga merupakan bayan alQuran (penjelasan mengenai isi kandungan al-Qur'an).

Hadis-hadis Nabi saw. termaktub dalam berbagai kitab hadis dan telah beredar di kalangan masyarakat luas. Dalam kitab-kitab hadis tersebut ditemukan banyak tema yang membicarakan tentang motivasi, kemuliaan atau keutamaan bagi orangorang yang mempelajari al-Qur'an. Bahkan, hadis-hadis tentang hal ini dibahas secara detail dalam kitab-kitab syarah hadis.

Tema belajar al-Qur'an dalam perspektif hadis, dapat ditelusuri dalam AlMu'jam al-Mufahras li al-Faz al-Hadis an-Nabawiy melalui lafal qara'a, ta'lim (ta'allama), ta'dib, tahfiz dan lafal-lafal lain yang terkait dengannya. Misalnya ilmu, al-'aql, al-fikr, dan al-hikmah. Lafal ta'lim (ta'allama) saja, telah ditemukan informasi dari Mu'jam 11 hadis, belum termasuk kata ta'lim dalam bentuk yang lain. Tema belajar al-Qur'an dapat pula dianalisis dari lafal tahfizh. Di samping terdapat dalam $M u^{\prime} j a m$ juga terdapat dalam Miftah Kunus al-Sunnah, dan dapat pula ditelusuri melalui CD-Room Hadis dalam program komputerisasi.

Berkaitan dengan tema kemulian belajar al-Qur'an, hadis-hadis yang tidak menggunakan lafal tersebut di atas, masih sangat banyak, namun masih memiliki relevansi dengan urgensi belajar al-Qur'an, sehingga dapat pula dikategorikan sebagai hadis tentang belajar al-Qur'an secara tematik. Misalnya saja, hadis tentang orang yang menyibukkan diri dengan al-Qur'an.

Banyaknya hadis Nabi saw. yang terkait al-Qur'an belajar al-Qur'an, adalah sesuatu yang wajar karena harus diakui bahwa dalam sejarah Nabi saw., diketahui bahwa beliau dalam setiap harinya senantiasa mendidik dan mengajar sahabat-sahabatnya membaca, menghapal dan memahami makna al-Qur'an. Apalagi al-Qur'an 
adalah kitab suci umat Islam yang menjadi petunjuk (hudan) dan penjelasan tentang kebaikan dan keburukan.

Allah swt. berfirman dalam Q.S. al-Anbiya (21): 10:

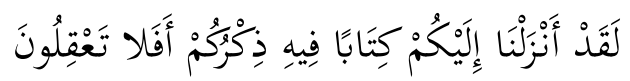

Sesungguhnya telah Kami turunkan kepada kamu sebuah kitab yang di dalamnya terdapat sebab-sebab kemuliaan bagimu. Maka apakah kamu tiada memahaminya? ${ }^{3}$

Nabi saw. selama hidupnya, telah memberi perhatian khusus terhadap pengajaran al-Qur'an. Respons dan stimulus Nabi saw. terhadap masalah ini, paling tidak dapat dilihat dari hadis-hadisnya. Karena itu, dapat dikatakan bahwa Islam sangat mengutamakan pengajaran al-Qur'an sebagai sumber petunjuk umat Islam yang mutlak kebenarannya.

Seiring dengan itu, perhatian dan gairah sahabatpun untuk belajar al-Qur'an sangat tinggi. Adanya motivasi dan sugesti berupa jaminan pahala dan kemuliaan bagi orang-orang yang belajar dan mengajarkan al-Qur'an yang diungkapkan dalam ayat-ayat dan hadis-hadis Nabi saw. menjadikan para sahabat berlomba-lomba mempelajari, menghapal dan mengajarkan al-Qur'an.

Kenyataan di atas, berimplikasi terhadap pentingnya penelitian hadis-hadis tentang belajar al-Qur'an yang terdapat dalam berbagai hadis, karena dalam ilmu hadis ditekankan status hadis yang boleh dijadikan hujjah.

\section{RUMUSAN MASALAH}

Berdasar latar belakang di atas, maka penulis merumuskan permasalahan sebagai berikut:

1. Bagaimana kualitas hadis tentang keutamaan belajar dan mengajarkan al-Qur'an?

2. Bagaimana keutamaan orang-orang yang belajar al-Qur'an dan mengajarkannya?

\section{METODE PENDEKATAN}

Pendekatan yang digunakan dalam penelitian ini adalah pendekatan filofis dengan penekanannya kepada aspek aksiologis. ${ }^{4}$ Dipadukan dengan teologis ${ }^{5}$ historis dan sosiologis. ${ }^{6}$ Adapun metode yang digunakan adalah metode maudhu'i dengan jalan mengidentifikasi semua hadis tentang keutamaan belajar dan mengajarkan alQur'an sebagai tema sentral kajian tulisan ini berdasarkan hadis yang menjadi objek pembahasan. Dengan melalui lafaz-lafaz hadis tentang pendidikan, baik dalam bentuk kata kerja, isim atau fi'il, lalu kemudian melakukan analisis teks dan kontekstual. Kemudian dilakukan klasifikasi dan selanjutnya dilakukan takhrij alhadis.

\section{Metode dan Teknis Analisis}

M. Syuhudi menyebutkan dua metode takhrij yaitu: 1) takhrij bi al-Lafz yakni penelusuran hadis Nabi saw. berdasarkan petunjuk lafaz yang ada pada hadis; 2) 
takhrij bi al-Maudhu'i yaitu penelusuran hadis Nabi berdasarkan tema atau topik masalah yang berhubungan dengan hadis yang diteliti. ${ }^{7}$

Berdasar pendapat tersebut di atas, penulis menilai bahwa teknik yang dikemukakan M. Syuhudi Ismail cukup praktis dan mudah diaplikasikan. Oleh karena itu, penulis memilih metode yang digunakan dalam men-takhrij hadis adalah penelusuran hadis Nabi berdasarkan lafaz atau suku kata dari matan hadis dengan mengunakan kamus petunjuk yakni kitab al-Mu'jam Mufahras li Alfadl al-Hadis alNabawi, yang merujuk pada 9 kitab hadis (kutub tis'ah), karangan Arnold J. Wensink.

Adapaun lafaz-lafaz yang dijadikan dalalah dalam penelusuran hadis yang sesuai dengan petunjuk kitab al-Mu'jam al-Mufahras li Alfadz al-Hadis al-Nabawi, adalah: lafaz dan تعلم 8 mengingat waktu yang sangat singkat untuk meneliti hadis secara sempurna.

Berdasarkan isyarat dari lafaz di atas, menunjukkan bahwa hadis-hadis mengenai belajar al-Qur'an dapat ditemukan dalam beberapa kitab-kitab hadis yang menjadi sumber primer, kemudian diklasifikasikan berdasarkan keragaman riwayat dari beberapa mukharrij.

\section{Klasifikasi}

Berdasarkan petunjuk takhrij dengan menggunakan kata تعلم dari beberapa kitab tersebut di atas, maka penulis menemukan 11 hadis dari 5 mukharrij. Adapun teksteks hadis dari tema atau hadis yang dipilih berdasarkan kitab hadis, sebagai berikut:

1. Shahih al-Bukhari, kitab fadhail al-Qur'an, bab khairukum man ta'alam al-Qur'an, hadis No. 4639.

2. Sunan at-Turmuziy, kitab fadhail Alquran 'an Rasulillah, bab ma ja'a fi ta'limil alQur'an hadis No. 2832 dan 2833.

3. Sunan Abu Daud, Kitab Shalat, bab fi tsawab qira'ati al-Quran, hadis No. 1240.

4. Sunan Ibn Majah, kitab muqaddimah, bab fadl ta'limil al-Quran, hadis No. 207.

5. Sunan ad-Darimy, kitab fadha'il Alquran bab khiyarukum man ta'allama al-Quran, hadis No. 3203.

6. Ahmad ibn Hanbal. Kitab musnad al-'asyarah al-mubasysyirina min al-jannah bab musnad 'Usman bin Affan, hadis No. 389.

Adapun tampilan teks hadisnya, dari klasifikasi takhrij di atas, sebagai berikut:

\section{Shahih al-Bukhari}

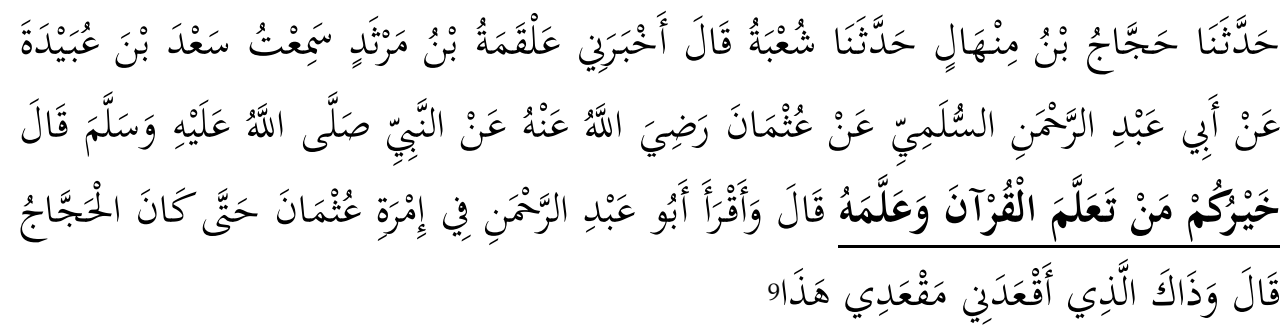




\section{Sunan al-Turmuziy}

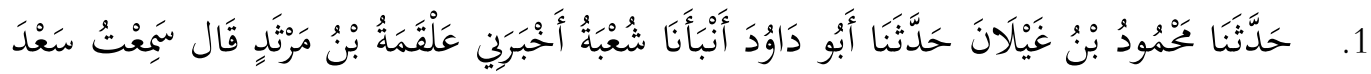

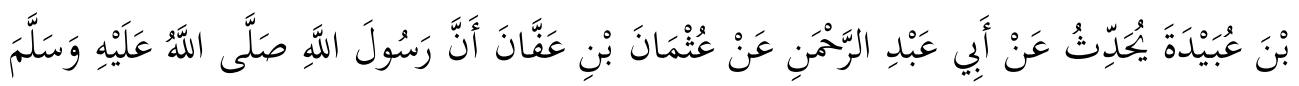

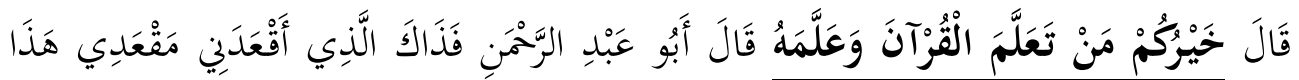

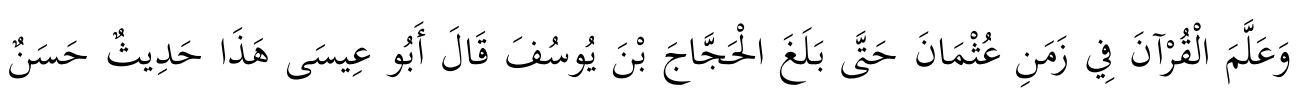

10 صَحِ

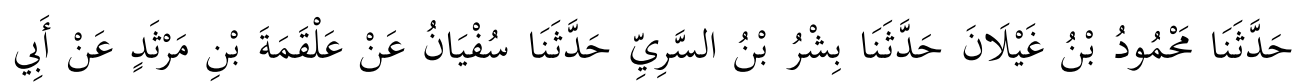

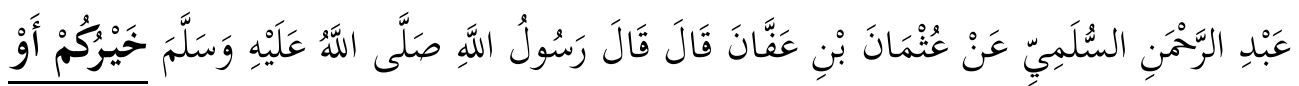

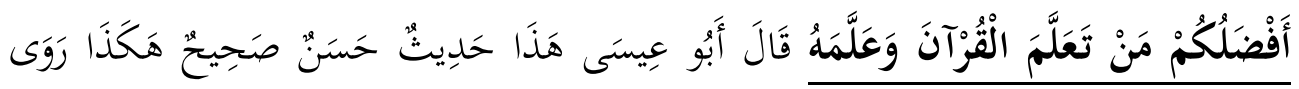

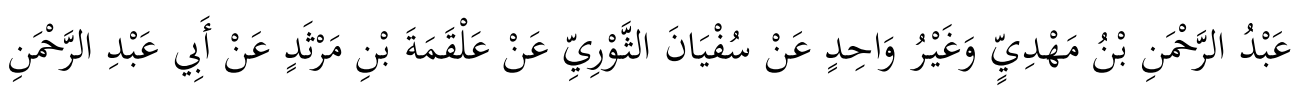

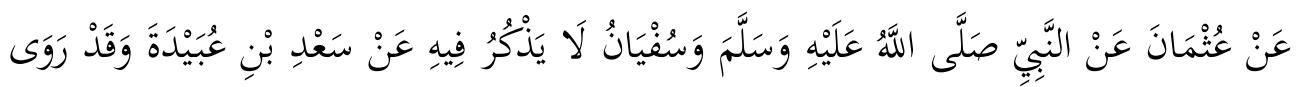

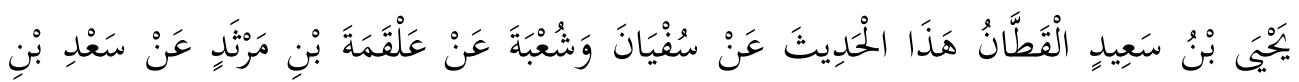

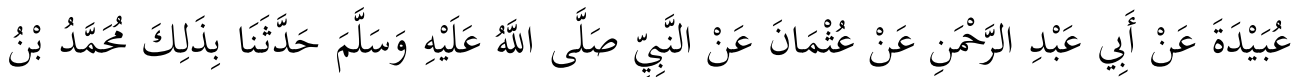

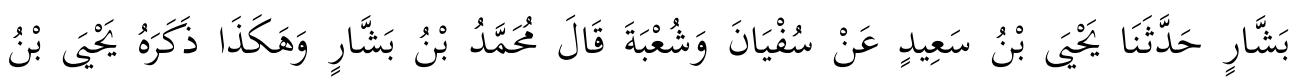

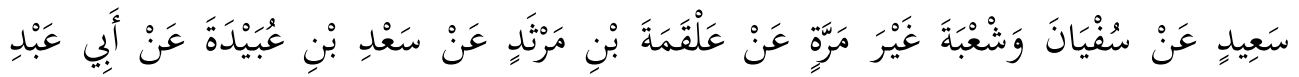

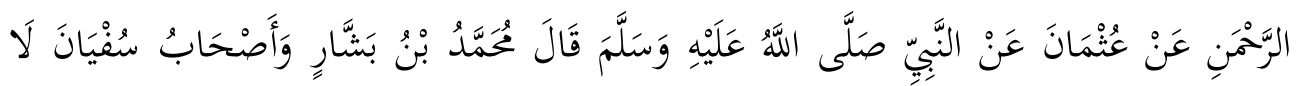

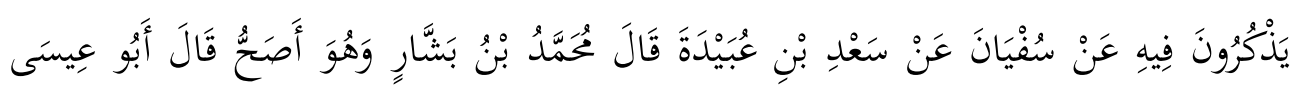

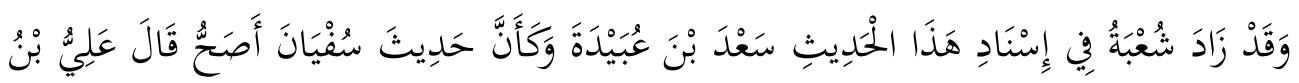

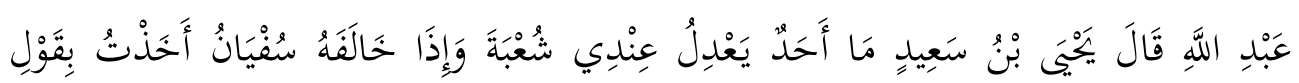

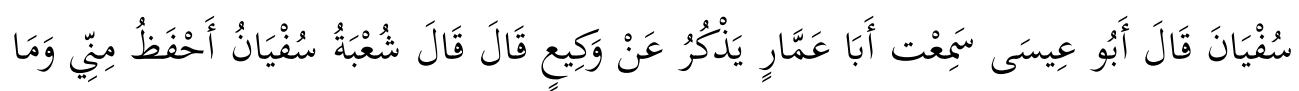

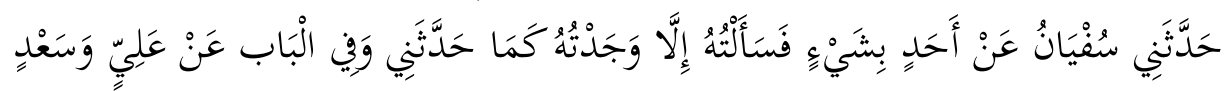

\section{Sunan Abu Daud}

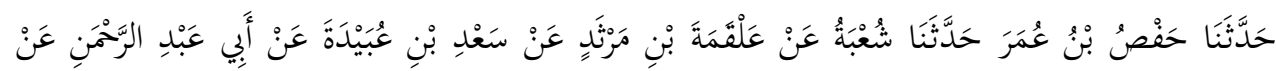

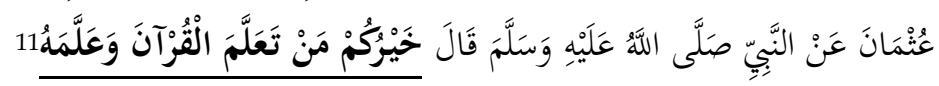




\section{Sunan Ibn Majah}

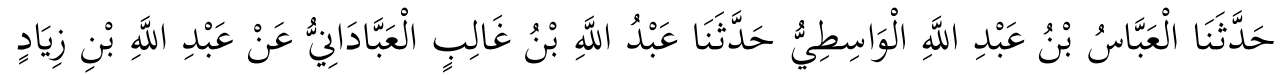

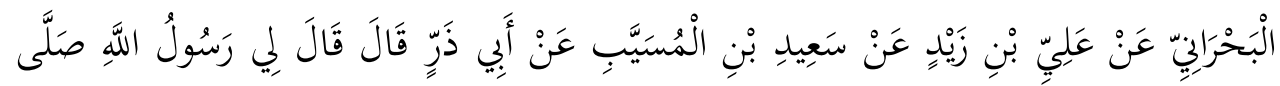

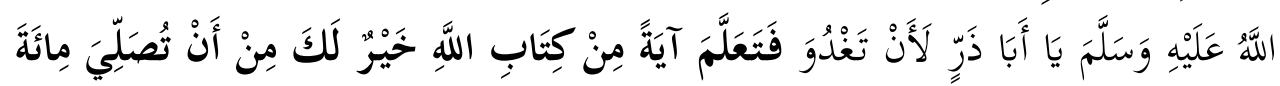

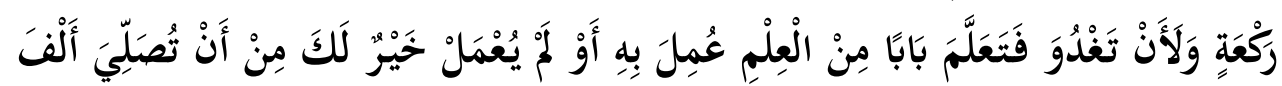

رَكْعَةٍ

\section{Sunan ad-Darimiy}

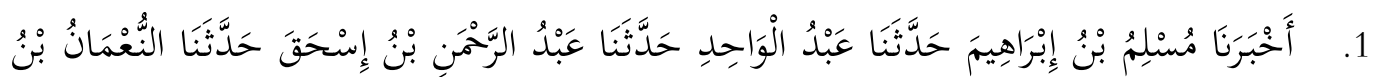

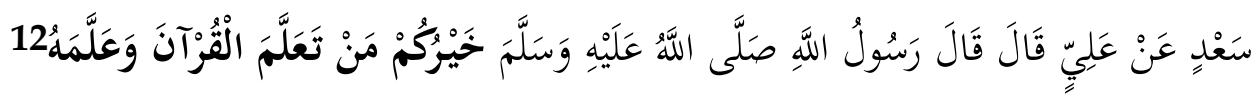

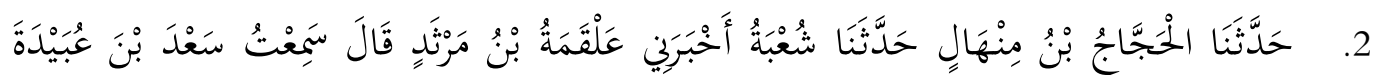

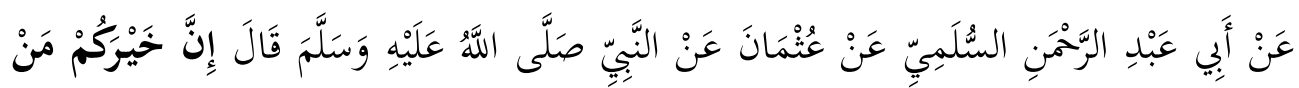

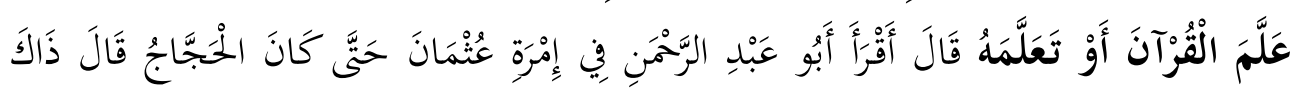

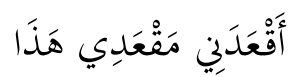

\section{Musnad Ahmad Ibn Hanbal}

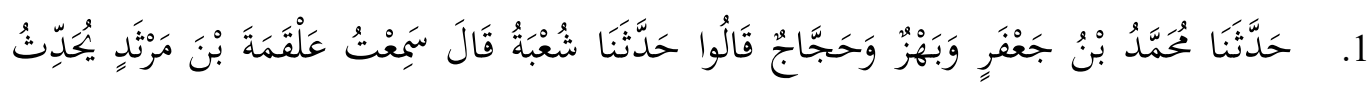

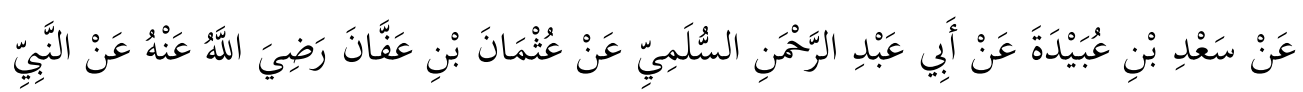

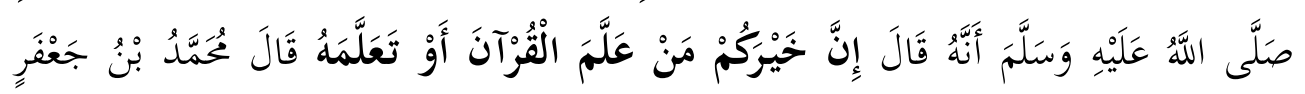

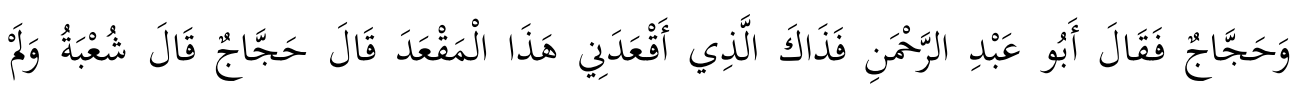

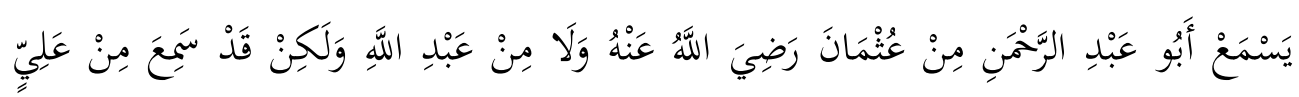

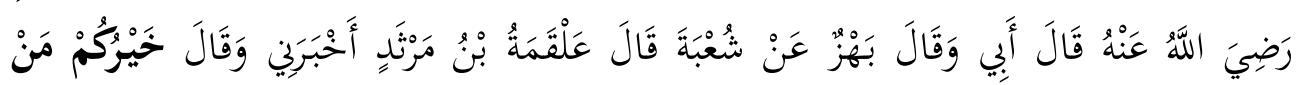

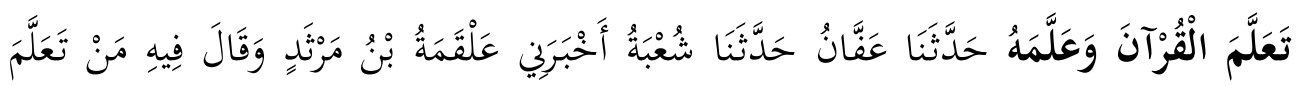

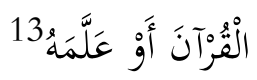

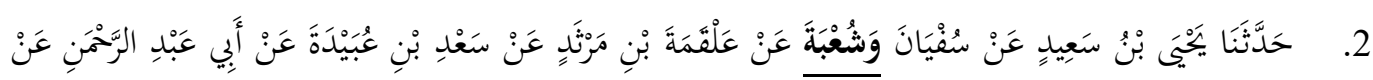

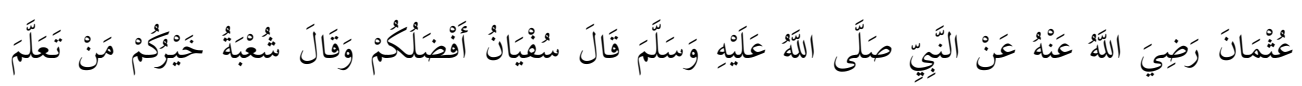
الُُْرْاَنَ وَعَلَّمَهُ 


\section{KRITIK SANAD DAN MATAN}

\section{Kritik sanad}

Kualitas sanad hadis merupakan hal yang sangat urgen dalam penelitian hadis, bahkan sebagian pendapat mengatakan bahwa kesahihan sanad menentukan penelitian selanjutnya terhadap penelitian matan. Jika sanadnya $d h a^{\prime} i f$, tidak perlu meneliti matannya.

Dalam kajian ini, teks hadis yang dipilih untuk dikritik adalah riwayat atTurmuziy, sebagai berikut:

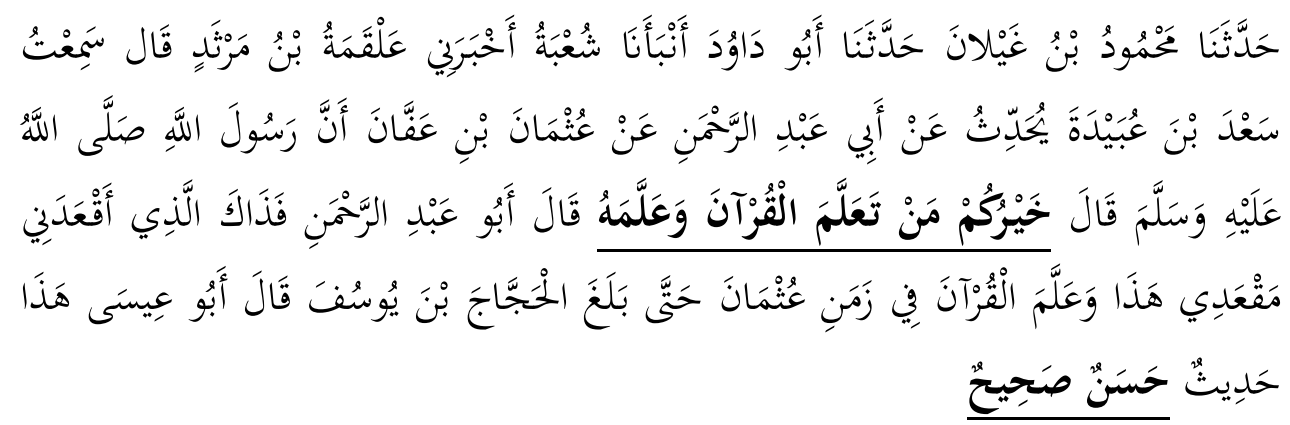

Sanad hadis tersebut melalui Mahmud bin Ghailan Tabi'in kalangan pertengahan, semasa hidup di Baghdad, Wafat: 239 H. An-Nasa'i, Ibnu Hibban, Maslamah bin Qasim, Ibnu Hajar al-'Asqalani menilainya Tsiqah dan Adz-Dzahabi menyatakan Hafizh. Abu Daud nama lengkapnya Sulaiman bin Daud bin Al-Jarud, Tabi'ut Tabi'in kalangan biasa, semasa hidup di Bashrah Wafat: $204 \mathrm{H}$, penilaian ulama: Ahmad bin Hambal menilai Tsiqah Shaduuq, Yahya bin Ma'in menyatakan Shaduuq, Al-'Ajli menilainya Tsiqah banyak hafalannya dan Adz-Dzahabi menyatakan al-hafidz. Syu'bah bin al-Hajjaj bin al-Warad, Tabi'ut Tabi'in kalangan tua, semasa hidup di Bashrah Wafat: $160 \mathrm{H}$. Al-'Ajli tsiqah tsabat Ibnu Sa'd tsiqah ma`mun, Abu Daud menyatakan tidak ada seorangpun yang lebih baik haditsnya dari padanya, Ats-Tsauri dia adalah amirul mukminin fil hadits, Ibnu Hajar al-Atsqalani tsiqoh hafidz, Adz-Dzahabi tsabat hujjah. Alqamah bin Martsad dari kalangan Tabi'in, semasa hidup di Kufah, Ibnu Hajar, Adz-Dzahabi, Ahmad bin Hambal, An-Nasa'i, dan Ibnu Hibban menilai Tsiqah. Sa'ad bin 'Ubaidah, Tabi'in kalangan pertengahan, semasa hidup di Kufah, Yahya bin Ma'in, An Nasa'i, Al 'Ajli, Adz-Dzahabi, Ibnu Hajar al 'Asqalani, dan Ibnu Hibban menilai Tsiqah. Abu 'Abdur Rahman Tabi'in kalangan tua, semasa hidup di Kufah Wafat: 72 H. Ulama kritikus hadis menilainya Tsiqah. Dan Utsman bin 'Affan bin Abi Al 'Ash bin Umayyah kalangan sahabat semasa hidup di Madinah Wafat: 35 H. ${ }^{14}$

At-Turmuzy menyimpulkan bahwa status hadis tentang kemulian belajar alQur'an dan mengajarkannya ini dinyatakan berkualitas hasan sahih.

Berdasarkan penilaian para kritikus hadis terhadap sanad hadis di atas, dapat dinyatakan bahwa rangkaian periwat hadis yang diriwayatkan oleh Imam AtTurmuzy tersebut adalah berkualitas sahih. 


\section{Kritik Matan}

Jika dilihat perbandingan redaksi hadis dari beberapa sumber atau riwayat di atas, ditemukan ada perbedaan redaksi walaupun itu tidak terlalu jauh, dan tidak memengaruhi makna hadis, seperti dalam riwayat at-Turmuzy dengan menambahkan kata afdhal, sebagai berikut:

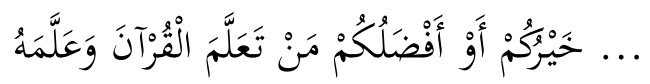

Redaksi lain dengan riwayat Ibn Majah, sebagai berikut:

$$
\begin{aligned}
& \text { أَفْضَنَلُكُمْ مَنْ تَعَلَّمَ الْقُرْاََنَ وَعَلَّمَهُ }
\end{aligned}
$$

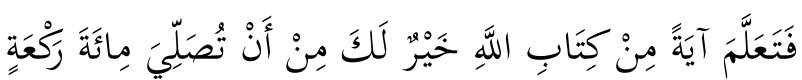

Redaksi hadis riwayat ad-Darimy, sebagai berikut:

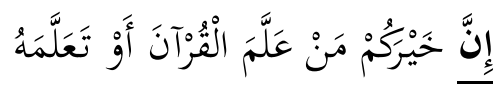

Dengan melihat keragaman redaksi hadi-hadis tersebut, telah memberikan indikasi bahwa hadis ini ada kemungkinan diriwayatkan oleh sahabat berdasarkan makna yang dipahami dari perkataan Rasulullah saw. (riwayah bi al-ma'na). Dengan adanya perbedaan redaksi dengan tambahan kata afdhal dan inna, maka harus dilakukan penelitian secara mendalam terhadap hadis ini untuk menentukan bahwa apakah tambahan tersebut adalah idraj (sisipan) ataukah ziyadah (tambahan).

Namun secara singkat, jika dilihat metode kritik matan hadis, maka tambahan pada teks hadis tersebut tidak memengaruhi makna dan tidak bertentangan dengan tiga unsur kesahihan matan dalam kritik matan hadis yaitu:

1. Tidak bertentangan dengan al-Qur'an

2. Tidak bertentangan hadis sahih, dan

3. Tidak bertentangan dengan akal sehat

Oleh karena itu, penulis berkesimpulan bahwa matan hadis tersebut sahih dan dapat dipertanggungjawabkan untuk dijadikan hujah dalam melaksanakan suatu ibadah yakni hadis ini dapat dijadikan dasar untuk memotivasi seseorang untuk mempelajari al-Qur'an demi mendapatkan kemulian dan selanjutnya mengajarkan kepada sesama muslim untuk kesempurnaan pahala.

\section{SYARAH HADIS}

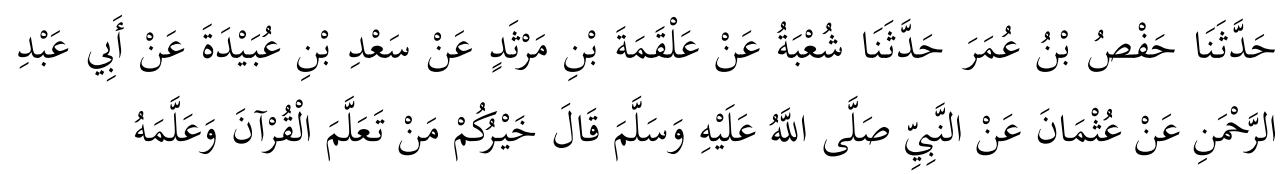

Kami diceritakan Hafsah bin 'Umar, kami diceritakan oleh Syu'bah dari 'Alqamah bin Martsad dari sa'din bin 'Ubaidah dari 'Abdirrahman dari 'Utsman dari Rasulullah saw. Beliau bersabda: sebaik-baik di antara kamu adalah orang yang belajar al-Qur'an, dan kemudian mengajarkannya. 
Dari teks hadis di atas, dapat digambarkan bahwa ada dua poin penting yang terkandung dalam hadis tersebut yang membuat seseorang mulia di antara orang lain, yakni mempelajari isi al-Qur'an dan kemudian mengajarkannya. Itu berarti, jika seseorang hanya mempelajari dan menguasainya, namun tidak mengajarkannya, maka ia belum termasuk orang yang belum terbaik di antara yang lain, karena dalam hadis ini ada dua syarat yang diberikan oleh rasul untuk menjadi manusia terbaik yakni belajar al-Qur'an dan mengajarkannya kepada orang lain.

Dalam syarah Fathul Bariy dijelaskan sebagai berikut:

$$
\begin{aligned}
& \text {... إثبات الخيرية المذكورة لمن فعل أحد الأمرين فيلزم أن من تعلم القرآن ولو لم يعلمه غيره } \\
& \text {. أن يكون خيرا ممن عمل بما فيه مثلا وإن ل لم يتعلمه أن من تعلمه وعلمه غيره أن يكون } \\
& \text { أفضل ممن عمل بما فيه من غير أن يتعلمه ول لم يعلمه غيره , أن يكون المراد بالخيرية من } \\
& \text { جهة حصول التعليم بعد العلم والذي يعلم غيره يحصل له النفع المتعدي بخلاف من يعمل } \\
& \text { فقط , بل من أشرف العمل تعليم الغير , فمعلم غيره يستلزم أن يكون تعلمه , وتعليمه } \\
& \text { لغيره عمل وتحصيل نفع متعد , ولا يقال لو كان المعنى حول النفع المتعدي لاشترك كل من } \\
& \text { علم غيره علما ما في ذلك , لأنا نقول القرآن أشرف العلوم فيكون من تعلمه وعلمه لغيره } \\
& \text { أشرف ممن تعلم غير القرآن وإن علمه فيثبت المدعي ـ ولا شك أن الجامع بين تعلم القرآن } \\
& \text { وتعليمه مكمل لنفسه ولغيره جامع بين النفع القاصر والنفع المتعدي ولذذا كان أفضل } 15
\end{aligned}
$$

Dari uraian di atas, dapat difahami bahwa belajar saja merupakan suatu kebaikan, apalagi belajar kemudian mengajarkannya (mengamalkannya), itu lebih baik, karena mengajarkannya atau mengamalkannya, itulah pembelajaran yang sebenarnya.

Pada hakikatnya hadis ini memberi motivasi kepada manusia khususnya umat Islam untuk senantiasa menyemarakkan pendidikan al-Qur'an yang merupakan hudan bagi manusia. Karena jika seorang muslim tidak mengetahui apalagi mengenal al-Qur'an, maka bagaimana mungkin ia mendapat petunjuk dan hidayah al-Qur'an.

Hampir semua masalah dalam kehidupan manusia telah disinggung oleh alQur'an dan dijelaskan oleh hadis, walaupun al-Qur'an hanya menyinggung setiap permasalahan secara universal atau secara prinsip saja, tidak menjelaskan secara detail.

Ada pertanyaan yang menarik yang ditujukan kepada diri sendiri sebagai muslim yaitu, "Mengapa saya harus belajar al-Qur'an, dan mengapa saya harus mengajarkannya?"

Berinteraksi dengan al-Qur'an adalah kenikmatan, tetapi kenikmatannya tidak dapat dirasakan dengan menceritakan saja. Ia akan terasa nikmat hanya jika menyelami ke dalamnya. Ia akan terasa indah jika kita tenggelam ke dasarnya.

Umat Manusia di dunia saat ini sekitar enam milyar. Di antara mereka, 
mungkin tidak sampai separuhnya yang muslim. Sebagian kecil di antara mereka yang berpegang pada al-Qur'an dan as-Sunah itu, dan tidak seberapa yang mau belajar al-Qur'an.

Kemudian, di antara mereka yang mau belajar al-Qur'an:

1. Berapa yang bisa membaca al-Qur'an?

2. Di antara mereka, berapa banyak yang merealisasikan kemauannya membaca alQur'an?

3. Di antara mereka yang mau membacanya, berapa yang konsisten dalam membacanya?

4. Di antara mereka yang konsisten membacanya, berapa yang mau menghafal alQur'an?

5. Di antara mereka yang mau menghafal al-Qur'an, berapa banyak yang hafal alQur'an?

6. Di antara mereka yang hafal al-Qur'an, berapa banyak yang mau mengajarkan alQur'an?

7. Di antara mereka yang mengajarkannya, berapa banyak yang konsisten dalam dakwah bil al-Qur'an? dan

8. Jika kita bertanya pada diri kita "Di manakah posisi saya saat ini?", dapatkah kita menunjukkannya dengan penuh kebanggaan?

Ketika seseorang dihadapkan pada peluang belajar al-Qur'an, sering muncul gangguan-gangguan yang menyebabkan dia menunda-nunda peluang tersebut. Dan mungkin selalu ada saja alasan yang seakan-akan masuk akal, sehingga tidak lagi merasa bersalah ketika tidak belajar al-Qur'an. Alasan kesibukan adalah alasan yang paling sering dikemukakan.

Ada dua kemungkinan seseorang enggan belajar al-Qur'an, pertama, mungkin karena ketidaktahuan mereka terhadap kemulian dan manfaat yang diperoleh mempelajari al-Qur'an, kedua, mungkin karena kesibukan duniawi, sehingga belajar al-Qur'an dianggap kepentingan kedua. Padahal, seandainya ia belajar al-Qur'an dan menguasainya, maka kepentingan duniawi lainnya akan terpenuhi.

Sehubungan dengan ini, penulis juga menyajikan hadis-hadis yang memiliki hubungan atau hadis yang semakna tentang manfaat dan kelebihan yang diperoleh orang yang belajar al-Qur'an, antara lain:

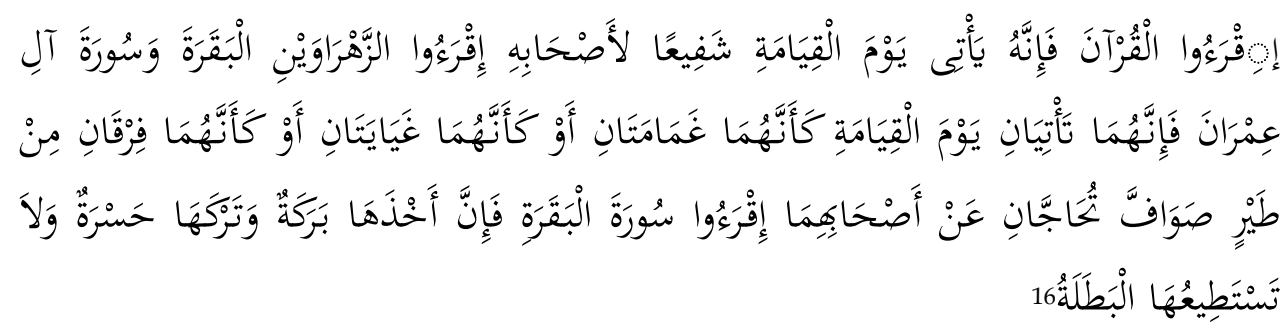

Bacalah al-Qur'an karena al-Qur'an akan datang pada hari kiamat nanti sebagai syafi' (pemberi syafa'at) bagi yang membacanya. Bacalah Az- Zahrowain (dua 
surat cahaya) yaitu surat al-Baqarah dan Ali ‘Imran karena keduanya datang pada hari kiamat nanti seperti dua awan atau seperti dua cahaya sinar matahari atau seperti dua ekor burung yang membentangkan sayapnya (bersambung satu dengan yang lainnya), keduanya akan menjadi pembela bagi yang rajin membaca dua surat tersebut. Bacalah pula surat al-Baqarah. Mengambil surat tersebut adalah suatu keberkahan dan meninggalkannya akan mendapat penyesalan. Para tukang sihir tidak mungkin menghafalnya."

Hadis ini menunjukkan bahwa orang yang menjadikan al-Qur'an sebagai sahabatnya di dunia, maka ia (al-Qur'an) itu dapat memberi syafaat bagi sipembacanya di akhirat kelak.

Dari Abu Musa al-Asy'ariy, Rasulullah saw. bersabda:

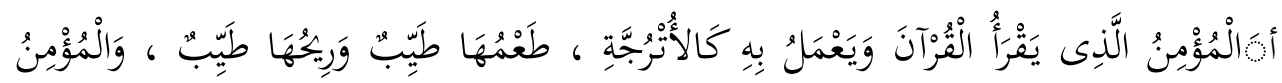

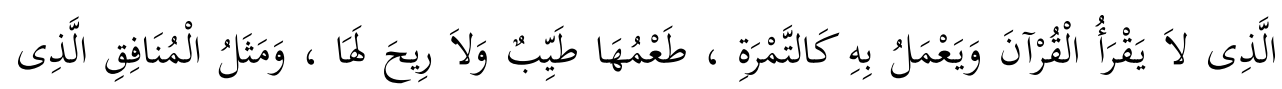

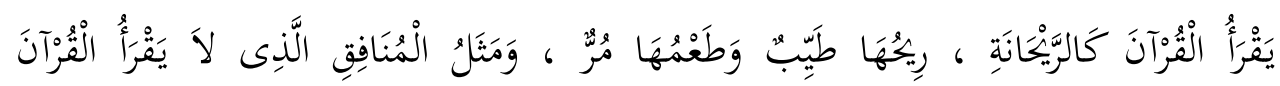

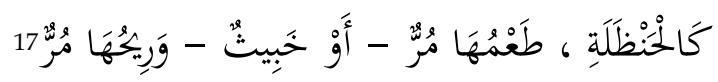

Permisalan orang yang membaca al-Qur'an dan mengamalkannya adalah bagaikan buah utrujah, rasa dan baunya enak. Orang mukmin yang tidak membaca al-Qur'an dan mengamalkannya adalah bagaikan buah kurma, rasanya enak namun tidak beraroma. Orang munafik yang membaca al-Qur'an adalah bagaikan royhanah, baunya menyenangkan namun rasanya pahit. Dan orang munafik yang tidak membaca al-Qur'an bagaikan hanzholah, rasa dan baunya pahit dan tidak enak.

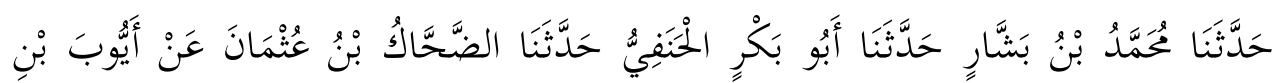

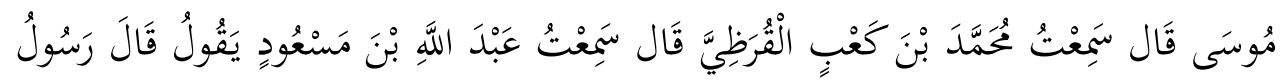

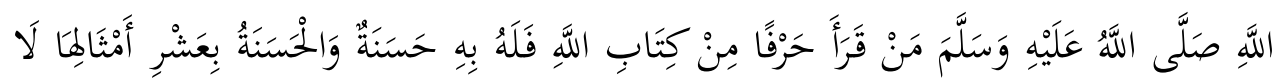

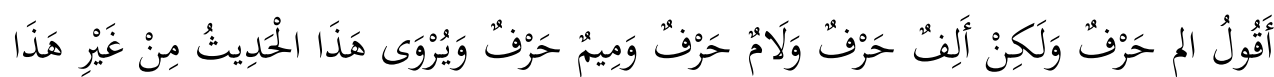

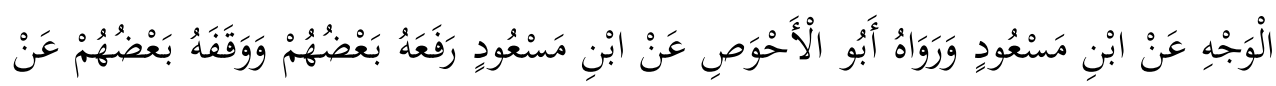

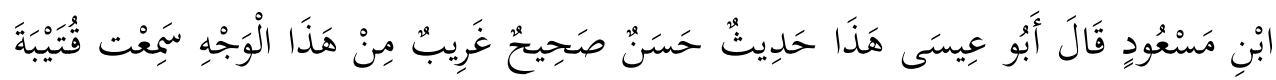

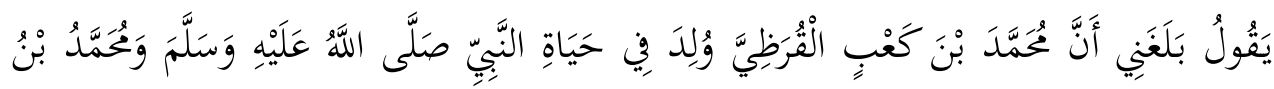

كَعْبِ يُكْنَى أَبَا حَمْزَهَ 18

Barangsiapa yang membaca satu huruf dari Al-Qur'an, maka baginya satu kebaikan. Satu kebaikan akan menjadi sepuluh kali lipat. Aku tidak mengatakan alif laam miim itu satu huruf, melainkan alif satu huruf, lam satu huruf dan mim satu huruf.

Dari Abdullah bin 'Amr, Rasulullah saw. bersabda: 


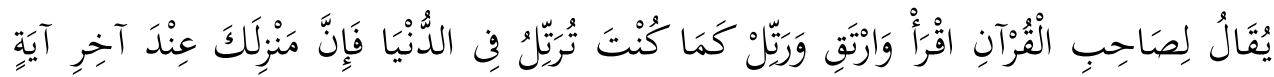

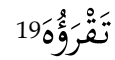

Dikatakan kepada orang yang membaca (menghafalkan) al-Qur'an nanti: ‘Bacalah dan naiklah serta tartillah sebagaimana engkau di dunia mentartilnya. Karena kedudukanmu adalah pada akhir ayat yang engkau baca (hafal).

Jika dilakukan pengembangan makna terhadap hadis ini, maka hadis di atas pada hakikatnya mengandung makna bahwa belajar al-Qur'an harus dimulai sejak dini atau sejak masih kecil, karena pendidikan al-Qur'an pada anak merupkan penentu dalam pembentukan kepribadiannya dan masa depan anak, agar tumbuh sebagai manusia yang mulia.

Betapa penting dan mulianya mempelajari al-Qur'an, sehingga Allah dapat mengalihkan azabnya dari suatu komunitas masyarakat yang masih ada orang di dalamnya mempelajari al-Qur'an. Rasulullah saw. Bersabda:

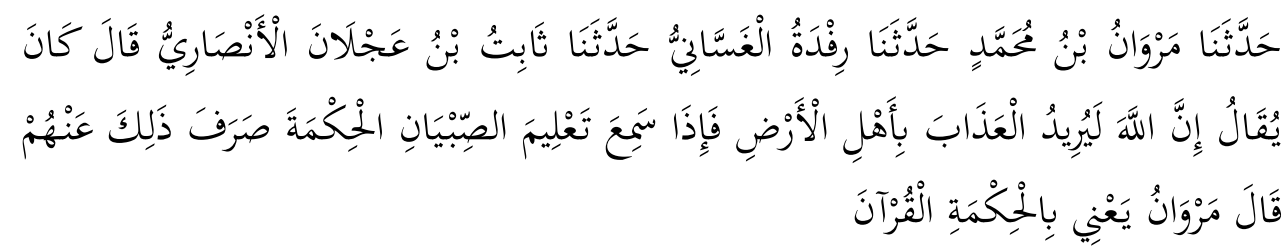

Telah menceritakan kepada kami Marwan bin Muhammad telah menceritakan kepada kami Rifdah al-Ghassani telah menceritakan kepada kami Tsabit bin 'Ajlan al-Anshari ia berkata: Dikatakan; Sesungguhnya Allah berkehendak untuk memberikan azab kepada penduduk bumi, namun ketika Dia mendengarkan beberapa anak kecil mempelajari Al-Hikmah, Dia memalingkan azab tersebut dari mereka. Marwan berkata; Yang dimaksud dengan Al-Hikmah adalah alQur'an. ${ }^{20}$

Dalam hadis lain disebutkan bahwa:

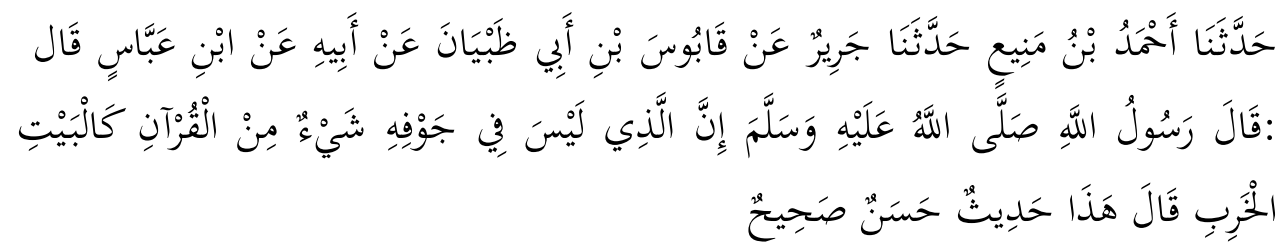

Telah menceritakan kepada kami Ahmad bin Mani' telah menceritakan kepada kami Jarir dari Qabus bin Abu Dzabyan dari Ayahnya dari Ibnu Abbas ia berkata: Rasulullah saw. bersabda: "Sesungguhnya orang yang di dalam dirinya tidak ada sedikit pun al-Qur'an ibarat rumah yang runtuh." Abu Isa berkata; Hadits ini hasan shahih. ${ }^{21}$

Ibnu Mas'ud sebagaimana dikutip Yusuf al-Qaradhawi berkata: al-Qur'an itu merupakan perjamuan Allah. Siapa yang mampu mempelajari sebagian darinya, maka hendaklah dia melakukannya. Sesungguhnya rumah yang paling kosong dari kebaikan ialah yang di dalamnya tidak ada sedikitpun dari bacaan Kitab Allah. ... 
menyerupai rumah roboh yang tidak ada penghuninya. Sesungguhnya syetan keluar dari rumah yang darinya terdengar surat al-Baqarah. ${ }^{22}$

Salah satu hadis yang cukup populer di kalangan umat Islam, walaupun hadis tersebut tidak secara langsung menyebut pendidikan al-Qur'an, namun melihat makna hadis secara komprehensip memberi gambaran bahwa pendidikan pada masa kecil oleh orang tuanya, khususnya pendidikan al-Qur'an, menentukan kepribadian dan cara bersikap anak ketika ia sudah dewasa. Adapun hadis yang dimaksud, sebagai berikut:

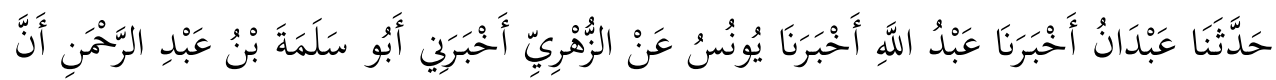

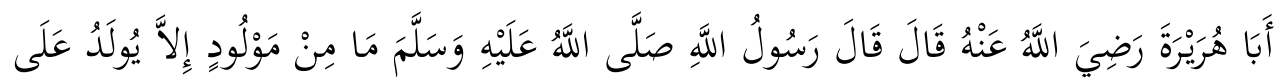

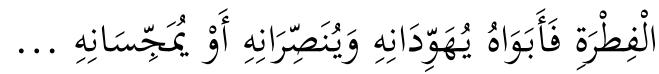

... tidak seorang pun anak yang dilahirkan kecuali dilahirkan dalam keadaan suci (fitrah) orang tuanyalah yang akan menentukan (mendidiknya) menjadi Yahudi, Nasrani, dan Majusi...

Dengan demikian, penulis memahami bahwa walaupun hadis tersebut sifatnya memberi motivasi, akan tetapi umat Islam tidak bisa mengelak dari belajar al-Qur'an sebagai kitab sucinya. Jadi, jelaslah bahwa pendidikan al-Qur'an atau belajar alQur'an harus ditanamkan pada anak sejak ia masih berusia dini dengan tujuan pembentukan kepribadian dan moral. Jika sudah demikian baru manusia dapat menjadikan al-Qur'an sebagai hudan (pedoman) hidup untuk mencapai status sebaikbaik manusia, sebagaimana yang dimaksud oleh tersebut.

\section{SIMPULAN}

Setelah menguaraikan beberapa hal mengenai keutamaan belajar al-Qur'an, maka penulis menyimpulkan bahwa:

1. Hadis-hadis tentang kemulian belajar al-Qur'an sangat banyak jumlahnya dan terdapat dalam al-kutb al-tis'ah dan diklasifikasikan secara mawdhu'i berdasarkan mukharrij. Hadis mengenai hal ini berkualitas sahih. Karena itu, kajian penulis ini berimplikasi pada pentingnya pengamalan hadis-hadis tentang kemulian belajar al-Qur'an dalam kehidupan untuk mendapat hidayah dari al-Qur'an.

2. Belajar al-Qur'an adalah suatu keniscayaan bagi umat Islam dan untuk menyempurnakan keutamaan al-Qur'an adalah mengajarkannya agar ilmu yang telah diperoleh dapat bermanfaat bagi orang lain. Ketika dua unsur itu sudah terpenuhi, maka dari segi ini persyaratan untuk mendapatkan peringkat manusia terbaik dapat tercapai menurut sabda Rasulullah saw. 


\section{CATATAN AKHIR:}

1. Abuddin Nata, Tokoh-tokoh Pembaruan Pendidikan Islam di Indonesia, Jakarta: PT. RajaGrafindo Persada, 2005, h. vi.

2. Abuddin Nata, Tokoh-tokoh Pembaruan Pendidikan Islam di Indonesia, h. 392.

3. Lihat lembar soal ujian komprehensif Program Doktor PPs UIN Syarif Hidayatullah Jakarta, tanggal 2 Mei 2005.

1. M. Quraish Shihab, Wawasan Al-Qur'an, Tafsir Tematik atas Pelbagai Persoalan Umat (Cet. II; Bandung: Mizan, 2007), h. 3.

2. Departemen Agama RI. Al-Qur'an dan Terjemahnya (Jakarta: Pustaka Agung Harapan, 2006), h. 385.

3. Ibid. h. 449.

4. Jujun S. Suriosumantri, Falsafah Islam Sebuah Pengantar Populer (Jakarta: Sinar Harapapn 1984), h. 232-236.

5. Abuddin Nata, Metodologi Studi Islam (Cet. IV; Jakarta: PT. Raja Grafindo Persada, 2002), h. 28-41.

6. Mahmud al-Tahhan Usul al-Takhrij wa Dirasah al-Asanid diterjemahkan oleh Ridwan Nasir dengan Judul Metode Takhrij dan Penelitian Hadis (Surabaya: Bina Ilmu, 1995), h. 5.

7. M. Syuhudi Ismail, Metodologi Penelitian Hadis Nabi (Cet. I; Jakarta: Bulan Bintang, 1988), h. 46.

8. A. J. Wensick. Concordance et Indices de la tradition Musulmane, diterjemahkan oleh Muhammad Fu'ad Abd al-Baqi' dengan judul al-Mu'jam al-Mufahras li Alfaz al-Hadis alNabawiy, Juz I (Leiden: E. J. Brill, 1936 M.), h. 109.

9. Abu Abdullah Muhammad bin Isma'il bin Ibrahim bin al Mughirah bin Bardizbah alBukhariy, Shahih al-Bukhariy kitab fadhail Al-Qur'an bab khairukum man ta'alam Al-Qur'an, hadis ke 4639.

10. Abu 'Isa Muhammad bin 'Isa bin Saurah bin Musa bin adl Dlahhak at-Turmuzy Sunan at-Turmuziy, kitab fadhail Al-Qur'an 'an Rasulillah, bab ma ja'a fi ta'limil Al-Qur'an hadis No. 2832 dan 2833.

11. Sulaiman bin al Asy'ats bin Syadad bin 'Amru bin 'Amir Abu Daud, Sunan Abu Daud, Kitab Shalat, bab fi Tsawab Qira'ati Al-Qur'an, hadis No. 1240.

12. Abdullah bin Abdurrahman bin al Fadhl bin Bahram bin Abdush Shamad Ad-Darimy, Sunan ad-Darimy, kitab fadha'il Al-Qur'an bab khiyarukum man ta'allama Al-Qur'an, hadis No. 3203.

13. Abu Abdillah Ahmad bin Muhamad bin Hanbal bin Hilal bin Asad, Musnad Ahmad bin Hanbal. Kitab musnad al-'asyarah al-mubasysyirina min al-jannah bab musnad 'Usman bin Affan, hadis No. 389.

14. Hadith Encylopedia ver. 1 [CD ROM], Harf Information Technology Company, 2000.

15. Program Digital CD Room, Fathul Bariy bi Syarh Sahih al-Bukhariy, kitab fadhail al-Qur'an.

16. Abdul Husain Muslim bin al Hajjaj bin Muslim bin Kausyaz al-Qusyairi an-Naisaburi, Sahih Muslim kitab shalat musafir dan qashr bab fadl qira'atul Al-Qur'an dan surah al-Baqarah hadis No. 1337.

17. Abu Abdullah Muhammad bin Isma'il bin Ibrahim bin al Mughirah bin Bardizbah alBukhriy, Sahih Bukhari kitab fadail Al-Qur'an bab itsmun man ra'a Al-Qur'an hadis No. 4671.

18. Abu 'Isa Muhammad bin 'Isa bin Saurah bin Musa bin adl Dlahhak at-Turmuziy, Sunan At-Turmuzy kitab fadail Al-Qur'an 'an Rasulillah bab maja fi man qara harfan min Al-Qur'an hadis No. 2835.

19. Sulaiman bin al Asy'ats bin Syadad bin 'Amru bin 'Amir Abu Daud, Sunan Abu Daud kitab shalah bab istihbab at-Tartil hadis No. 1252.

20. Abdullah bin Abdurrahman bin al-Fadhl bin Bahram bin Abdush Shamad. Sunan ad- 
Darimi (CD Progam Musu'ah al-Hadis al-Syarif) No. Hadis 3211.

21. Abu 'Isa Muhammad bin 'Isa bin Saurah bin Musa bin adl Dlahhak. Sunan at-Tirmizi (CD Progam Musu'ah al-Hadis | al-Syarif) No. Hadis 2837.

22. Yusuf al-Qaradhawi, Kaifa Nata'amal Ma'a al-Qur'an diterjemahkan oleh: Kathur Suhardi dengan judul: Bagaimana Berinteraksi Dengan Al-Qur'an (Cet. I; Jakarta: Pustaka al-Kautsar, 2000), h. 143.

\section{DAFTAR PUSTAKA}

Abu Daud, Sulaiman bin al Asy'ats bin Syadad bin 'Amru bin 'Amir. Sunan Abu Daud, Kitab Shalat, bab fi Tsawab Qira'ati Al-Qur'an, hadis No. 1240.

Ahmad bin Muhamad bin Hanbal bin Hilal bin Asad, Abu Abdillah. Musnad Ahmad bin Hanbal. Kitab musnad al-'asyarah al-mubasysyirina min al-jannah bab musnad 'Usman bin Affan, hadis No. 389.

Al-Bukhariy, Abu Abdillah Muhammad bin Isma'il bin Ibrahim bin al Mughirah bin Bardizbah. Shahih al-Bukhariy, kitab fadhail Al-Qur'an bab khairukum man ta'alam AlQur'an, hadis ke 4639.

Ad-Darimy, Abdullah bin Abdurrahman bin al Fadhl bin Bahram bin Abdush Shamad. Sunan ad-Darimy, kitab fadha'il Al-Qur'an bab khiyarukum man ta'allama Al-Qur'an, hadis No. 3203.

Departemen Agama RI. Al-Qur'an dan Terjemahnya, Jakarta: Pustaka Agung Harapan, 2006.

Hadith Encylopedia ver. 1 [CD ROM], Harf Information Technology Company, 2000.

Ismail, M. Syuhudi. Metodologi Penelitian Hadis Nabi, Cet. I; Jakarta: Bulan Bintang, 1988.

M. Quraish Shihab, Wawasan Al-Qur'an, Tafsir Tematik atas Pelbagai Persoalan Umat. Cet. II; Bandung: Mizan, 2007.

Muslim bin al Hajjaj bin Muslim bin Kausyaz al-Qusyairi an-Naisaburi, Abdul Husain. Sahih Muslim kitab shalat musafir dan qashr bab fadl qira'atul Al-Qur'an dan surah al-Baqarah hadis No. 1337.

Nata, Abuddin. Metodologi Studi Islam, Cet. IV; Jakarta: PT. Raja Grafindo Persada, 2002.

Program Digital CD Room, Fathul Bariy bi Syarh Sahih al-Bukhariy, kitab fadhail al-Qur'an.

Al-Qaradhawi, Yusuf Kaifa Nata'amal Ma'a al-Qur'an diterjemahkan oleh: Kathur Suhardi dengan judul: Bagaimana Berinteraksi Dengan Al-Qur'an, Cet. I; Jakarta: Pustaka alKautsar, 2000.

Suriosumantri, Jujun S. Falsafah Islam Sebuah Pengantar Populer , Jakarta: Sinar Harapapn 1984.

At-Tahhan Mahmud. Usul al-Takhrij wa Dirasah al-Asanid diterjemahkan oleh Ridwan Nasir dengan Judul Metode Takhrij dan Penelitian Hadis, Surabaya: Bina Ilmu, 1995.

At-Turmuzy, Abu 'Isa Muhammad bin 'Isa bin Saurah bin Musa bin adl Dlahhak. Sunan atTurmuziy, kitab fadhail Al-Qur'an 'an Rasulillah, bab ma ja'a fi ta'limil Al-Qur'an hadis No. 2832 dan 2833.

Wensick, A. J. Concordance et Indices de la tradition Musulmane, diterjemahkan oleh Muhammad Fu'ad Abd al-Baqi' dengan judul al-Mu'jam al-Mufahras li Alfaz al-Hadis al-Nabawiy, Juz I (Leiden: E. J. Brill, 1936 M. 